\title{
The impact of talent management on job satisfaction of registered nurses in Malawian public hospitals
}

\begin{abstract}
Authors:
George L. Dzimbiri ${ }^{1}$ (1)

Alex Molefi² (D)

Affiliations:

${ }^{1}$ Department of Business Management, School of

Business and Economic Sciences, Malawi University of Business and Applied Sciences, Blantyre, Malawi

${ }^{2}$ Department of Industrial Psychology, Faculty of Industrial Psychology and Human Resource Management, North-West University, Mafikeng, South Africa
\end{abstract}

Corresponding author: George Dzimbiri, gdzimbiri@poly.ac.mw

Dates:

Received: 11 Nov. 2020

Accepted: 01 June 2021

Published: 23 Aug. 2021

How to cite this article: Dzimbiri, G.L., \& Molefi, A. (2021). The impact of talent management on job satisfaction of registered nurses in Malawian public hospitals. SA Journal of Human Resource Management/SA Tydskrif vir Menslikehulpbronbestuur, 19(0), a1513. https://doi.org/ 10.4102/sajhrm.v19i0.1513

\section{Copyright:}

(c) 2021. The Authors.

Licensee: AOSIS. This work is licensed under the

Creative Commons

Attribution License.

\section{Read online:}

Scan this QR
code with your
smart phone or
mobile device
to read online.

Orientation: Job satisfaction is the paramount tool to gauge whether employees are willing to stay or leave an organisation. Talent management as a key aspect of human resources management has a fundamental role to play in ensuring that employees are satisfied with their work so that they can stay within the organisation.

Research purpose: The purpose of this study was to establish the impact of talent management on job satisfaction of registered nurses in public hospitals of Malawi.

Motivation for study: There is a need for scientific knowledge concerning the connection between talent management and job satisfaction of registered nurses in public hospitals of Malawi as limited studies have been conducted in the Malawian context despite the nursing profession witnessing a dire voluntary attrition of nurses leading to severe shortages of nurses.

Research approach/design and method: The study uses a quantitative design by way of a cross - sectional survey method to determine the impact of talent management practices on job satisfaction of registered nurses. Data were collected from a sample of 834 registered nurses from the four main public hospitals of Malawi that were purposively selected. An adapted version of Minnesota Job Satisfaction Questionnaire (MSQ) combined with Human Capital Index questionnaire was administered to 834 nurses. Finally , 580 responses were found to be acceptable for analysis.

Main findings: The findings of the study demonstrate that talent management practices do not contribute towards job satisfaction of registered nurses in Malawian public hospitals . Regression analysis indicated that amongst nine elements of talent management practices, the predictors that are most effective in predicting the job satisfaction of registered nurses include, staffing, talent development and talent deployment.

Practical/managerial implication: The results of this study underscore the problematic nature of implementing talent management practices in public hospitals of Malawi. Management of public hospitals should appreciate these results as poor talent management practices can reduce job satisfaction among employees.

Contribution/value add: The findings, therefore, add to the body of knowledge on how talent management practices can contribute to job satisfaction.

Keywords: talent management; job satisfaction; nursing; public; hospitals; registered nurses; Malawi.

\section{Introduction}

Job satisfaction has been of great importance to both individuals and organisations for many years, and this holds true also for healthcare organisations. It can, therefore, be observed that job satisfaction can be conceived as one of the imperative considerations concerning nurses working in hospitals (Anlesinya, Amponsah-Tawiah, \& Dartey-Baah, 2019). Most importantly, talent management is one of the fundamental tools that human resources personnel use to hone employees' satisfaction in the 21st century (Skinner, Madison, \& Humphries, 2017). Employees are a more pivotal resource than any other resources such as capital and physical resources for organisations to survive in a globally competitive and technologically advanced environment (Dzimbiri, 2016).

The literature suggests that talent management is one of the pivotal factors in job satisfaction (Khatun, Akter, Muhammad, \& Chowdhury, 2018). An upsurge in employees' satisfaction leads to a large value and benefits for organisations and their workforces. Talent management that encourages employee satisfaction prevents competent employees from leaving the organisation as this could have adverse effects on performance and service delivery (Hafez, AbouelNeel, \& 
Elsaid, 2017; Ozuem, Lancaster, \& Sharma, 2016). This is inconsonant with the international nursing literature that views job satisfaction as a major contributory factor for employees' intent to stay (Crowley-Henry, Benson, \& $\mathrm{Al}$ Ariss, 2018; Mousa \& Ayoubi, 2019).

The Malawian government has been committed to providing support to the healthcare system for the attainment of universal health coverage and quality life for Malawians. Thus, the government not only effected the Emergency Human Resource Programme (EHRP), which augmented the number of health workers in 11 priority cadres from 5453 to 8369 between 2004 and 2009, but also implemented a variety of talent management strategies to improve availability, retention and performance of human resources for health (HRH, 2016). Accordingly, initiatives such as career schemes, improvement of professional opportunities, free postgraduate training, free hot meals for night duty staff in hospitals and over-time pay were implemented in the healthcare system (HRH, 2016).

However, the Malawian nursing profession continues to face various challenges, most crucially, a shortage of registered nurses because of voluntary attrition amidst perhaps insufficient talent management practices (HRH, 2018). Some estimates indicate that Malawi's nursing profession suffers a significant attrition rate of $3 \%$ per annum (HRH, 2018). Yet, it is evident in studies of other countries that the application of talent management practices may contribute towards employee satisfaction, and satisfied workforces tend to stay in an organisation (Ingram, 2016; Othman \& Sumardi, 2014). This reality clearly demonstrates that the job satisfaction of registered nurses is of paramount importance, because of its direct impact on the quality of nursing care and because it is evident that inadequate number of nurses affect patient care (Khatun et al., 2018; Lindfors, Meretoj, Kaunonen, \& Paavilainen, 2017). This is indicative of the fact that hospital management in conjunction with the government needs to consider carefully implemented strategies such as talent management practices to increase the job satisfaction levels of nurses in public hospitals.

It is therefore imperative to determine the impact of talent management on job satisfaction amongst registered nurses in Malawi's public hospitals to determine how talent management has a bearing on job satisfaction of these nurses in the Malawian context.

Talent management and job satisfaction have been extensively studied in the global context (Awan \& Muhammad, 2016; Hamidi, Saberi \& Safari, 2014; Kamal \& Lukman, 2017; Tash, Ali, \& Ahmadzedeh, 2016). Results suggest that talent management considerably affects job satisfaction whilst correlation analysis reveals that talent management is positively correlated with job satisfaction of employees in various contexts. However, very little academic research has been conducted on the impact of talent management on job satisfaction, particularly within the Malawian context. This study establishes the impact of talent management on the job satisfaction levels of registered nurses in public hospitals of Malawi.

The study makes numerous insights. Firstly, the context is an important contribution of this study in the sense that the relationship between talent management and job satisfaction was tested within the Malawian context and this has not been performed before; hence more information was obtained to validate the adapted instruments. Secondly, the study is imperative for accountability as it helps the in-depth understanding of nurses about the talent management practices being implemented and be able to hold their authorities accountable regarding how they should be implemented. Thirdly, the study is also necessary for advocacy as it helps to advance and promote how talent management practices should be implemented to support best practices in public hospitals.

Apart from this introduction, the article provides a theoretical review of talent management and job satisfaction, respectively, and an analysis of their relationship. Subsequently, it presents a research approach and methods before presenting results and discussion. Thereafter, it presents the conclusion and, finally, the recommendations.

\section{Talent management}

The talent management concept has been defined differently by both academics and practitioners. What emerges, therefore, is that different disciplines have defined talent management differently, so that a common definition and meaning is not agreed upon. According to Ramli, Isa, Baharin and Ibrahim (2018), talent management is deemed as the systematic attraction, identification, development, engagement, retention and deployment of those employees who are of particular value to an organisation, either given their high potentials for the future or because they are fulfilling business or operation-critical roles. This implies that talent management comprises deliberately set management activities and practices established by the organisation to retain, maintain, sustain and attract an exceptional workforce for high organisational productivity.

Obinna (2015) considered talent management as a process that encompasses four variables, namely talent identification, talent development, talent utilisation and talent retention. In a similar vein, Salvador, Fernandez and Maria (2017) viewed talent management as the process of recruiting, involving, enhancing, retaining and deploying talents. According to Tyskbo (2019), talent management is a process that includes a complete and interrelated set of organisational activities such as identifying, selecting, developing and retaining the best employees, as well as building their potential for the most strategic positions and assisting them in applying their strengths to gain their engagement and contribution, which ultimately contribute towards organisational benefits (Devi, 2017).

A conclusion from the definitions can be made, therefore, that talent management involves a range of systematic interrelated 
activities, and their effective application within the organisation with the purpose of yielding a competitive advantage.

Literature has widely highlighted the benefits of talent management at different levels. Most importantly, talent management helps an organisation to retain potential talent in an organisation. Similarly, talent management practices can serve as important instruments to facilitate the achievement of employee outcomes such as retention, commitment, organisational citizenship behaviour, performance, motivation, job satisfaction and work engagement (King, 2015; Ramli, Isa, Baharin, \& Ibrahim, 2018; Wahba, 2015). It can also create various organisational outcomes such as employer attractiveness, quality service delivery, creation of appealing employer brand, competitive advantage and financial performance, as well as macro-level outcomes like industry and national competitiveness and the achievement of sustainable development goals (Almeida, Fernando, \& Munoz, 2019; Stoffers \& Van der Heijden, 2014; Whysall, Owtram, \& Brittain, 2019).

According to Mohamed (2017), talent management has positive effects on talented employees' performance and negative effect on counterproductive behaviours in the Ghanaian banking industry. Similarly, Mensah and Bawole (2017) suggested that talent management does not only have a direct effect, but also an indirect effect on talented employees' affective commitment and decreased quit intentions via person-job fit working in selected parastatal institutions in Ghana. Furthermore, studies performed in South Africa found that talent management practices are used to retain talents in the parastatal institution in the aviation sector (Ngozwana \& Rugimbana, 2011). This finding also supports the findings of a study by Plessis, Barkhuizen, Stanz and Schutte (2015), which showed that talent management practices are negatively related to intention to quit in the South African recruitment industry.

In previous studies conducted in other continents on the impact of talent management on job satisfaction, results show that talent management significantly affects job satisfaction whilst correlation analysis showed that talent management is positively correlated with job satisfaction of employees in various contexts (Awan \& Muhammad, 2016; Hamidi, Saberi, \& Safari, 2014; Kamal \& Lukman, 2017; Tasha, Ali, \& Ahmadzadeh, 2016).

Similarly, a study in South Africa reveals that employees included in the organisational talent pool reported higher relational and transactional psychological contract, organisational commitment, organisational citizenship behaviour, trust and the intention to stay with organisations compared to non-talent pool members. Furthermore, studies performed in South Africa found that talent management practices are used to retain talents in parastatal institutions in the aviation sector (Ngozwana \& Rugimbana, 2011). This finding also supports Du Plessis et al.'s (2015) finding that shows that talent management practices are negatively related to intention to quit in the South African recruitment industry.
Additionally, Plessis et al. (2015) conducted a study on the management side of talent management, exploring causal implications for the retention of Generation $Y$ employees. The findings indicate that perceived organisational support is significantly related to talent management practices, perceived supervisor support and intention to quit. Furthermore, Barkhuizen (2014) performed a study on the relevance of talent management in South African local government institutions, and found that talent management practices are poorly applied in local government institutions.

At the organisational level, Maheshwari et al. (2017) indicated that in the banking sector in Mauritius, effective talent management can attract the best talent which will, in turn, help to create a distinct competitive advantage for the firm and enhance their employer branding and employer attractiveness.

Mousa and Ayoubi (2019) found that exclusive talent management has a significant effect on organisational downsizing, whereas inclusive talent management has an insignificant effect. Relatedly, with a study on the Egyptian architecture, engineering and construction (AEC) industry, Othman and Khalil (2018a) revealed that talent management reduces demotivation, but does not significantly influence the creativity of architectural firms. In another context, Nafei (2015) indicateed that talent management positively affects a firm's service quality performance. Thus, it is obvious that talent management can improve various firm-level outcomes.

In addition, there have been empirical studies on the concept and practice of talent management in Kenya. One of the informative studies was carried out by Mukweyi (2016) on the influence of talent management practices at Kijabe Mission hospital. The results show that talent management practices had a positive impact on the retention of health workers. Similarly, Mwanzi, Wamitu and Kiama (2017) conducted a study on the influence of talent management on organisational growth of a private hospital. The findings show that talent identification is important for organisational growth, because in order to effectively nurture and manage talent, organisations need to be able to identify the right talent and provide a suitable environment for talent utilisation.

Drawn from the empirical studies highlighted in the global contexts, the researcher has observed that there has been much progress on talent management studies in the African context; however, there is still a need for more research in various African contexts because talent management practices are applied differently in different contexts and consequently impact employees differently. According to the researcher's best knowledge, there is no similar research study that was conducted in the context of a Malawian nursing profession regarding talent management and its impact on job satisfaction of professional nurses in the public hospitals of Malawi. Therefore, this academic research seeks to bridge that gap in the literature with the aim of advancing knowledge of talent management and its impact on job satisfaction, especially in the Malawian context. 


\section{Job satisfaction}

Job satisfaction is a complex and multifaceted concept that has multiple meanings to different scholars. According to Kumar and Manisha (2018), job satisfaction is viewed as a worker's emotional state of accomplishment and achievement on the work. Generally, it is argued that job satisfaction is associated with production as well as the health of individuals at work. In other words, job satisfaction involves what employees enjoy doing, doing it perfectly and being rewarded for one's efforts. It could also mean enthusiasm and being happy with one's work. This implies that job satisfaction is a key factor leading to income, recognition, promotion and attainment of other goals that lead to a sense of fulfilment.

According to Thanh and Nguyen (2016), job satisfaction is the sum total of emotions, feelings, views and beliefs that people hold of their present jobs. The levels of people's job satisfaction can range from extreme satisfaction to extreme dissatisfaction. Besides having perceptions and attitudes about one's job as a whole, employees can also have attitudes about various aspects of their jobs, such as the kind of jobs they do, their fellow employees, their managers or subordinates and their salaries. In addition to these, other aspects related to attitudes include the kind of work they do, their co-workers, supervisors or subordinates and their pay (Nguyen, 2016). Therefore, job satisfaction involves the state of mind and attitude that employees have at their workplace. When employees have an affirmative and good attitude towards their jobs, it is a sign of job satisfaction (Ariana, Soleimanib, \& Oghazianc, 2018). On the other hand, when employees develop an unfavourable attitude towards their jobs, it is an indication of job dissatisfaction (Ariana et al., 2018).

Kahiga (2018) pointed out that job satisfaction is crucial within an organisation, because there are many consequences associated with job dissatisfaction. These, amongst others, include a lack of loyalty, an increased number of accidents and increased absenteeism. To achieve the benefits of job satisfaction within an organisation, Kahiga (2018) listed three important features of job satisfaction that organisations need to take into consideration. Firstly, organisations should make sure that they are guided by human values, in the sense that they should prioritise treating employees equally and with respect. Thus, an analysis of job satisfaction can serve as a good indication of worker effectiveness. When levels of job satisfaction are high, this may also indicate a good emotional and mental state of workers. Secondly, the behaviour of workers, depending on the level of job satisfaction, tends to influence the activities and the functioning of the organisation. Given this, job satisfaction tends to cause positive behaviour whilst job dissatisfaction causes negative behaviour amongst workers. Thirdly, job satisfaction is a sign of organisational activities in the sense that with job satisfaction assessments, various levels of satisfaction in various company units can be explained, but in return can serve as a good indication of which organisational unit should be changed with the aim of increasing productivity (Kahiga, 2018).
From the foregoing literature review, the following hypothesis is derived:

H1: There is a positive relationship between talent management and job satisfaction.

\section{Research methodology}

The study employed quantitative research design using a cross-sectional survey strategy. According to Cooper and Schindler (2013), a cross-sectional survey design is wellsuited to the descriptive and predictive functions associated with correlational research, whereby relationships between variables are examined.

\section{Population and sample}

The target population of the study was registered nurses in the four Central hospitals of Malawi, namely, Queen Elizabeth Central hospital, Zomba Central hospital, Kamuzu Central hospital and Mzuzu Central hospital.

A purposive sampling technique was used to select the four central hospitals because they constitute a larger number of registered nurses than other public hospitals in Malawi (MoH, 2018). The respondents for each hospital were selected by way of a simple random sampling where every subject had every chance of being selected. Using the Cochran formula (1963), a sample of 834 nurses were drawn from a population of 8334 registered nurses, at $95 \%$ confidence level and a marginal error of $3 \%$.

\section{Data collection}

The study relied on primary data. The primary data were collected using self-administered questionnaires. An adapted version of short form of the Minnesota Job Satisfaction (MSQ) was utilised to measure the impact of talent management on job satisfaction of registered nurses in public hospitals of Malawi and talent management was measured by using the Human Capital Index Questionnaire. An adapted questionnaire of short form of the Minnesota Job Satisfaction (MSQ) was utilised in order to include all items that were considered relevant to public hospitals of Malawi. The questionnaire had two sections. The first part was the 'Introduction', a section showing demographic information of the participants. The second part was the 'Research design section', the section which dealt with registered nurses' perception regarding the nine elements of talent management impacting job satisfaction. These were strategy, talent review process, staffing, talent acquisition, talent engagement, talent development, talent deployment, performance management and talent retention. The reliability of this tool was already confirmed in many studies in South Africa (Barkhuizen \& Veldsman, 2012). The short form of MSQ comprised of 20 items ( 1 item per aspect) partitioned into intrinsic and extrinsic job contexts. The items were adapted to reflect the impact of talent management on job satisfaction of professional nurses in a way that the original items were not distorted. Nine hundred and forty-seven questionnaires were administered to 
respondents for a period of 3 months and 598 questionnaires were returned. Out of these responses, only 580 responses representing a response rate of $61.2 \%$ were useful for analysis.

\section{Ethical considerations}

Permission to carry out research was sought from the NorthWest University and Directors of selected public hospitals in Malawi through their Research Ethics Committees for their approval before carrying out the research process. Questionnaires were distributed randomly and manually by giving them to the participants in the hand after a comprehensive explanation of the purpose of the research. The participants took part in the study voluntarily and the confidentiality and anonymity of the subjects were respected.

\section{Data management}

The data were manually coded, cleaned and captured in excel sheet before imported into Stata version-16.1 statistical software for analysis. The data summaries were generated in order to produce frequencies tables, Bar graphs and percentages. The reliability of the measuring instruments was determined by using Cronbach Alpha Coefficients. The validity was confirmed using Confirmatory Factor Analysis (CFA) through Structural Equation Modelling (SEM). The adequacy of the sample was confirmed using the Kaiser Mayer Olkin (KMO) measure of sampling adequacy as a prerequisite for conducting CFA. Factorability of the correlation matrix was checked using Bartlett's test of sphericity.

\section{Results of the study Demographic information}

The study participants were mostly female, over half (66.6\%), and $33.4 \%$ of them were males. Less than half of the respondents
(42.2\%) were in the age group of between 25 and 30 years of age. In terms of their marital statuses, it was observed that $53.8 \%$ of the respondents were married. Most participants were educated up to diploma (55.6\%) and it was also observed that $44.8 \%$ of them were in middle management whilst $30.5 \%$ of the respondents were in the lower management. Furthermore, about half of the respondents (55.2\%) had less than 6 years of work experience whilst $16.9 \%$ of the respondents had less more than 11 years of work experience.

\section{Reliability analysis}

The Cronbach Alpha Coefficients were used to determine the reliability of the measuring instrument. When the alpha is 0.70 or higher, it is considered acceptable in most social research situations (Cheng, 2013; Perrin, 2014; Phomnuisuk \& Omar, 2016). Results indicated that the overall Cronbach's Alpha was greater than 0.9 (Table 1), implying that the items of the short form of the Minnesota Job Satisfaction Questionnaire (MSQ) were excellently reliable and hence there was no need to drop items to improve reliability. Besides, all the Corrected ItemTotal Correlation values were above 0.3. According to Gliner, Morgan and Leech (2011), such values are good and pointed out that none of the items should be dropped from analysis.

The factorability of the 20 items of MSQ was also examined and the $\mathrm{KMO}$ was found to be greater than 0.7 indicating sampling adequacy, and factor analysis was, therefore, useful with MSQ (Gliner et al., 2011; Scott \& Nahamin, 2017). Bartlett's test of sphericity was also significant $\left(\chi^{2}[190]=6720.306\right.$, $p<0.01$ ), hence the items were factorable (Elmi et al., 2017; Gliner et al., 2011). Likewise, CFA was also conducted and based on Kaiser's rule of Eigenvalues greater than 1, three factors from MSQ were retained and were further explored to establish construct for job satisfaction. Firstly, three factors together account for $61.065 \%$ of the total.

TABLE 1: Item-Total Statistics for Minnesota Job satisfaction Questionnaire.

\begin{tabular}{|c|c|c|c|c|}
\hline Item for job satisfaction & $\begin{array}{l}\text { Scale Mean if item } \\
\text { deleted }\end{array}$ & $\begin{array}{l}\text { Scale Variance if } \\
\text { item deleted }\end{array}$ & $\begin{array}{l}\text { Corrected item-total } \\
\text { correlation }\end{array}$ & $\begin{array}{l}\text { Cronbach's Alpha if } \\
\text { item deleted }\end{array}$ \\
\hline I am able to keep busy all the time in this hospital because of talent management & 50.91 & 195.264 & 0.5065 & 0.9426 \\
\hline In this hospital, I have the chance to work alone on the job because of talent management & 50.81 & 192.696 & 0.5676 & 0.9417 \\
\hline Talent management ensures that I get the chance to do different things at this hospital & 50.95 & 191.615 & 0.649 & 0.9403 \\
\hline Talent management has given me chance to become some body and a ctive at work & 50.87 & 190.715 & 0.6778 & 0.9398 \\
\hline The way my supervisor handles his or her workers has improved because of talent management & 50.94 & 191.478 & 0.6657 & 0.94 \\
\hline Because talent management intervened the skills gap in management has been closed & 50.99 & 193.572 & 0.6217 & 0.9407 \\
\hline Talent management has taught me to be able to do things on my own without much help & 50.79 & 190.385 & 0.6741 & 0.9398 \\
\hline The use of talent management by management ensures steady employment & 51.00 & 190.214 & 0.6948 & 0.9395 \\
\hline Talent management has given me the chance to do things for other people by involving them fully & 51.02 & 189.565 & 0.7024 & 0.9394 \\
\hline I have the chance to tell people what to do because of the skills I got from talent management & 50.81 & 188.434 & 0.7095 & 0.9392 \\
\hline I was enlightened about policies with the help of talent management & 50.95 & 189.820 & 0.706 & 0.9393 \\
\hline Talent management ensures that hospital policies are put into practice & 50.86 & 189.797 & 0.6704 & 0.9399 \\
\hline Talent management has negotiated for a good pay against the amount of work I do & 51.48 & 196.271 & 0.4906 & 0.9428 \\
\hline Talent management has increased the chances for advancement on this job in this hospital & 51.30 & 192.909 & 0.6075 & 0.9409 \\
\hline I have the freedom to use my own judgment in this hospital because of talent management & 51.02 & 191.817 & 0.6348 & 0.9405 \\
\hline The implementation of talent management in this hospital has given me the chance to grow & 51.14 & 192.355 & 0.6394 & 0.9404 \\
\hline Talent management has created good working conditions for me in this hospital & 51.13 & 189.737 & 0.7015 & 0.9394 \\
\hline The way my co-workers get along with each other is a result of talent management & 51.09 & 189.164 & 0.722 & 0.939 \\
\hline The praise I get for doing a good job is a result of talent management & 51.07 & 189.020 & 0.7032 & 0.9393 \\
\hline I feel a great sense of accomplishment from my job because of talent management & 51.07 & 189.172 & 0.7075 & 0.9393 \\
\hline
\end{tabular}


The study adopted benchmarks for interpreting fit indices from Hooper, Coughlan and Mullen (2008). Results indicate that the standardised root mean squared residual (SRMR $=6.598)$ was above the cut-off of 0.08 (Table 2). The comparative fit index was low $(\mathrm{CFI}=0.678)$. CFI values of 0.90 or above are considered evidence of acceptable fit (Hooper, Coughlan \& Mullen, 2008). The root mean squared error of approximation (RMSEA) value (0.14) was large $(>0.08)$. All indices indicated a poor model fit to the data.

Results that indicated coefficient estimates were statistically significant $(p<0.001)$ as shown (Table 3). All individual items (job satisfaction 1 to job satisfaction 20) were positive and important to explain the relationship between talent management and job satisfaction through the components; work itself, salary and welfare and interpersonal relationship, hence none of the paths were dropped from the model as the proposed components were valid (Yung, 2010).

Results show that overall, $47 \%$ of participants were neutral about talent management contribution on job satisfaction (Figure 1). A total of $32.5 \%$ and $6 \%$ of participants were dissatisfied and very dissatisfied, respectively. And, $13.8 \%$ of them indicated being satisfied with the contribution of talent management to job satisfaction and less than $1 \%$ of the participants were very satisfied.

\section{Discussion}

The aim of the study was to determine the impact of talent management on job satisfaction of registered nurses in public

TABLE 2: Confirmatory factor analysis for job satisfaction.

\section{Fit summary}

\begin{tabular}{lc}
\hline Standardised root mean squared residual (SRMR) & 6.598 \\
Root mean squared error of approximation (RMSEA) & 0.14 \\
Comparative fit index (CFI) & 0.678
\end{tabular}

hospitals of Malawi. The results are discussed according to the hypothesis set for the study:

H1: There is a positive relationship between talent management and job satisfaction.

The results of the study were not consistent with the hypothesis and literature as a significant percentage of respondents, however, felt dissatisfied with the contribution of talent management to job satisfaction. It is worth noting that various studies in literature have demonstrated positive relationship between talent management and job satisfaction (Bhatnagar, 2007; Ingram, 2016; Schreuder \& Noorman, 2019; Shalonda, 2019; Sinclair-Maragh, Jacobs-Gray, \& BrownRoomes, 2017). In view of the findings of the study, the hypothesis set for the study was rejected.

\section{Recommendations}

Based on the findings of the study, the following recommendations are made to public hospitals.

It is recommended that management should be committed to talent management by making sure that talent

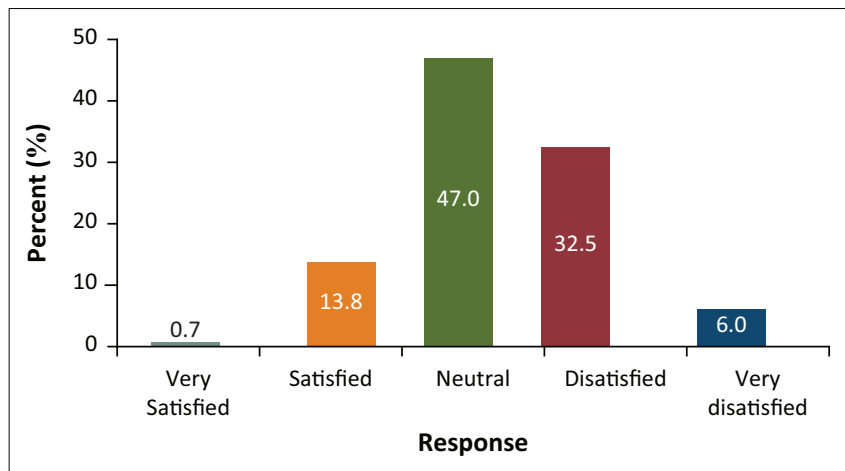

FIGURE 1: Overall participant's responses regarding the impact of talent management on job satisfaction.

TABLE 3: Path coefficients.

\begin{tabular}{|c|c|c|c|c|c|}
\hline Path & Parameter & Estimate & Std. Error & $Z$ & $p>|z|$ \\
\hline Work Itself -> d_job_satisfaction_1 & d_job_satisfaction_1 & 0.965688 & 0.00318 & 303.69 & $<0.0001$ \\
\hline Work Itself ->d_job_satisfaction_2 & d_job_satisfaction_2 & 0.974051 & 0.00256 & 380.55 & $<0.0001$ \\
\hline Work Itself -> d_job_satisfaction_3 & $d_{-}$job_satisfaction_3 & 0.976486 & 0.002352 & 415.19 & $<0.0001$ \\
\hline Salary_and_Welfare ->d_job_satisfaction_4 & d_job_satisfaction_4 & 0.971073 & 0.002494 & 389.37 & $<0.0001$ \\
\hline Salary_and_Welfare ->d_job_satisfaction_5 & d_job_satisfaction_5 & 0.970329 & 0.002553 & 380.07 & $<0.0001$ \\
\hline Salary_and_Welfare ->d_job_satisfaction_6 & $d_{-}$job_satisfaction_6 & 0.967606 & 0.00277 & 349.28 & $<0.0001$ \\
\hline Salary_and_Welfare ->d_job_satisfaction_8 & d_job_satisfaction_8 & 0.971672 & 0.002446 & 397.23 & $<0.0001$ \\
\hline Salary_and_Welfare ->d_job_satisfaction_9 & d_job_satisfaction_9 & 0.969509 & 0.002616 & 370.56 & $<0.0001$ \\
\hline Salary_and_Welfare ->d_job_satisfaction_10 & d_job_satisfaction_10 & 0.973119 & 0.00233 & 417.59 & $<0.0001$ \\
\hline Salary_and_Welfare ->d_job_satisfaction_11 & d_job_satisfaction_11 & 0.971913 & 0.002427 & 400.54 & $<0.0001$ \\
\hline Salary_and_Welfare ->d_job_satisfaction_12 & d_job_satisfaction_12 & 0.96762 & 0.00277 & 349.34 & $<0.0001$ \\
\hline Interpersonal_Relations ->d_job_satisfaction_13 & d_job_satisfaction_13 & 0.936264 & 0.005282 & 177.25 & $<0.0001$ \\
\hline Interpersonal_Relations -> d_job_satisfaction_14 & d_job_satisfaction_14 & 0.957863 & 0.003592 & 266.69 & $<0.0001$ \\
\hline Interpersonal_Relations ->d_job_satisfaction_16 & d_job_satisfaction_16 & 0.967347 & 0.002842 & 340.33 & $<0.0001$ \\
\hline Interpersonal_Relations -> d_job_satisfaction_17 & d_job_satisfaction_17 & 0.970508 & 0.002584 & 375.59 & $<0.0001$ \\
\hline Interpersonal_Relations ->d_job_satisfaction_18 & d_job_satisfaction_18 & 0.974032 & 0.002305 & 422.61 & $<0.0001$ \\
\hline Interpersonal_Relations -> d_job_satisfaction_19 & d_job_satisfaction_19 & 0.969841 & 0.002642 & 367.15 & $<0.0001$ \\
\hline Interpersonal_Relations ->d_job_satisfaction_20 & d_job_satisfaction_20 & 0.969882 & 0.002638 & 367.65 & $<0.0001$ \\
\hline
\end{tabular}


management systems of public hospitals are embedded in their strategic plans at the same time, and there is a need to commit adequate resources towards the talent management system. Management should also foster effective talent management practices for health workers, particularly registered nurses in order to advance their job satisfaction. Management of public hospitals, therefore, needs to recognise the critical role that effective talent management has towards job satisfaction and affect them accordingly in public hospitals of Malawi.

\section{Implication for theory}

This study contributes to the impact of talent management practices on job satisfaction in public hospitals of Malawi. Limited studies have been performed in this area, therefore the research provides additional awareness about this occurrence. The results of the study contribute to talent management and job satisfaction. The study advances an understanding of how registered nurses are satisfied with the existing talent management practices within the public hospitals of Malawi.

\section{Implication for policy and practice}

The study has revealed the problematic nature of talent management practices such as poor talent strategy, staffing levels, retention strategies and performance management. Management of public hospitals can utilise these results to manage talented nurses in order to enhance their job satisfaction. Furthermore, the study has highlighted the need for talent management practices such as strategy, talent review process, staffing, talent deployment, talent development, performance management and talent retention in public hospitals as they impact positively on job satisfaction. For hospitals to advance job satisfaction of their health workers, particularly, registered nurses, they must abandon the traditional way of handling talented nurses. The study assisted in fostering systematic talent management practices implementation by making sure that talent management systems of public hospitals are embedded in their strategic plans as well as committing adequate resources towards the talent management system.

\section{Limitations and suggestions for future research}

The study employed a cross-sectional survey design which bounds the study in terms of producing cause and effect inferences over the long period of time. Furthermore, the study was conducted in public hospitals particularly central hospitals of Malawi only, as such the findings cannot be generalised to other public and private hospitals. The other limitation was to do with the unit of study that focused on registered nurses only. This deprived study provides the opportunity of obtaining different views from other health workers such as doctors, hospital administrators, clinicians and dentists. Future research might consider a comparative study on talent management and its impact on job satisfaction for private nurses and public hospital nurses. Future studies should consider incorporating all health workers.

\section{Contribution of the study}

There have been few studies performed on the relationship between talent management and job satisfaction. The findings of this study therefore add significantly to the body of knowledge on talent management and job satisfaction. The results of this study also add to the understanding of the nature of nurses' talent management practices which could assist public hospitals in managing it. It further provides a better understanding of the nurses' talent management practices and their impact on job satisfaction. This could benefit the health sector as a whole.

\section{Conclusion}

The purpose of this study was to determine talent management and its impact on job satisfaction of registered nurses. A review of literature showed a gap within the body of knowledge with regard to the nurses' job satisfaction. The finding of the study was that talent management practices did not contribute to job satisfaction of registered nurses. The results further revealed the problematic nature of implementing talent management practices in public hospitals. Hence, management of public hospitals should pay particular attention to effective talent management of nurses as it advances job satisfaction.

\section{Acknowledgements}

The author would like to acknowledge the North-West University EMS-Research Committee and Committee on Social Science and Humanities of Malawi for issuing ethical clearance certificates and the Management of Central Hospitals for granting permission, and the research assistants for their dedication.

\section{Competing interests}

The authors have declared that no competing interest exists.

\section{Authors' contributions}

G.L.D. was involved in the conceptualisation, methodology, data collection, analysis of the study, writing, review and editing. A.M. was involved in supervision and review.

\section{Funding information}

This research received no specific grant from any funding agency in the public, commercial or not-for-profit sectors.

\section{Data availability}

The data are put in such a way that names of the respondents are not disclosed, hence the use of accession codes, and about two figures have included the raw data and there is no any restriction to data availability. 


\section{Disclaimer}

The views and opinions expressed in this article are those of the authors and do not necessarily reflect the official policy or position of any affiliated agency of the authors.

\section{References}

Almeida, B., Shamika, N., Fernando, K., Mario, F., \& Munoz, A. (2019). Retaining health carers: The role of personal and organisation job resources. Journal of Organizational Effectiveness: People and Performance, 16(2), 98-113. https://doi org/10.1108/JOEPP-06-2018-0036

Ariana, M., Soleimanib, M., \& Oghazianc, M. (2018). Job satisfaction and the factors affecting satisfaction in nurse educators: A systematic review. Journal of Professional Nursing, 13(5), 102-122. https://doi.org/10.1016/j.profnurs. 2018.07.004

Awan, A., \& Muhammad, H. (2016).Talent management practices and their impact on job satisfaction of employees: A case study of banking sector in Pakistan. Science International (Lahore), 28(4), 39-43.

Barkhuizen, N. (2014). How relevant is talent management in South Africa local government institutions? Mediterranean Journal of Social Sciences, 5(20), 2223 https://doi.org/10.5901/mjss.2014.v5n20p2223

Barkhuizen, N., \& Verdsman, S. (2012). Work engagement of academic staff in South African higher education institutions: Management dynamics. Journal of Southern Africa Institute for Management Scientists, 15(1), 38.

Bhatnagar, J. (2007). Talent management strategy employee engagement in India ITES employees: Key to retention. Employee Relations, 29(6), 640-663. https://doi. org/10.1108/01425450710826122

Cheng, Y. (2013). Statistical analysis of human growth and development (1st ed.). New York, NY: Chapman and Hall/CRC Press.

Cooper, J., \& Schindler, W. (2013). Research design: Qualitative, quantitative, and mixed methods approaches (4 ed.). Los Angeles, CA: Sage.

Crowley-Henry, A., Benson, M., \& Al Ariss, A. (2018). Linking talent management to traditional and boundaryless career orientations: Research propositions and future directions. European Management Review, 16(1), 5-19. https://doi. org/10.1111/emre.12304

Devi, A. (2017). The influence of Human resource management on knowledge sharing and innovation in Spain: The mediating role of affective commitment. The International Journal of Human resources Management, 22(7), 1442-1463. https://doi.org/10.1080/09585192.2011.561960

Dzimbiri, L.B. (2016). Organisation and management theories: An African focus (2nd ed.) Zomba: Academic Book Publishers.

Elm, S., Hassankhan, H., Abdollahzadeth, F., Abadi, M.A.J., Scott, J., \& Nahamin, M. (2017). Validity and reliability of the Persian practice environment scale of nursing work index. Iranian Journal of Nursing and Midwifery Research, 22(2), 106. https://doi.org/10.4103/1735-9066.205953

Gliner, J.A., Morgan, G.A., \& Leech, N.L. (2011). Research methods in applied settings: An integrated approach to design and analysis. Routledge: Oxford University press.

Hafez, E., AbouellNeel, R., \& Elsaid, E. (2017). An exploratory study on how talen management affects employee retentions and job satisfaction for personnel
administration in Ain Shams University. Journal of Management and Strategy, 8(4), 1-17. https://doi.org/10.5430/jms.v8n4p1

Hamidi, N., Saberi, H., \& Safari, M. (2014).The effect of implementation of talent management on job satisfaction governmental organizations * (Case Study: Ministry of Roads and Urban). Journal of Novel Applied Sciences, 3(1) Ministry

Hooper, D., Coughlan, J., \& Mullen, M. (2008). Structural equation modelling Guidelines for determining model fit. Electronic Journal of Business Research Methods, 6(1), 53-60.

HRH. (2016). National healthcare quality and disparities report (Report No. 18-0033EF). Malawi Department of Health and Human Services, Lilongwe: Government Press.

HRH. (2018). National healthcare quality and disparities report (Report No. 23 0043-EF). Malawi Department of Health and Human Services, Lilongwe: Government Press.

Ingram, T. (2016). Relationships between talent management and organizational performance: The role of climate for creativity. Journal of Entrepreneurial Business and Economics Review, 4(3), 195-205. https://doi.org/10.15678/EBER.2016. 040315

Kahinga, K. (2018). Factors influencing the job satisfaction of nurses working in obstetric units in public hospitals in Kenya. Journal of Nursing Education and Practice, 8(2), 132-146. https://doi.org/10.5430/jnep.v8n2p132

Kamal, M.Y., \& Lukman, Z.M. (2017). The relationship between attracting talent and job satisfaction in selected public higher learning institutions. International Journal of Management Research \& Review, 7(4), 444-449. https://doi. org/10.5958/2249-7307.2017.00087.1

Khatun, R., Akter, N., Muhammad, F., \& Chowdhury, A. (2018). Job satisfaction among nurses in public and private sector in Dhaka City of Bangladesh: A comparative study. International journal of Community Medicine and Public Health, 5(6), 2177-2181. https://doi.org/10.18203/2394-6040.ijcmph20182141
King, A. (2015). Global talent management. Journal of Global Mobility, 3(3), 273-288. https://doi.org/10.1108/JGM-02-2015-0002

Kumar, M., \& Manisha, A. (2018). Organisational talent management and perceived employer 312-330. https://doi.org/10.1108/IJOA-04-2017-1147

Maheshwari, V., Gunesh, P., Lodorfos, G., \& Konstantopoulou, A. (2017). Exploring HR practitioners' perspective on employer branding and its role in organisational attractiveness and talent management. International Journal of Organizational Analysis, 25(5), 742-761. https://doi.org/10.1108/IJOA-03-2017-1136

Mensah, J.K., \& Bawole, J.N. (2017). Person-job fit matters in parastatal institutions: Testing the mediating effect of person-job fit in the relationship between talent
management and employee outcomes. International Review of Administrative management and employee outcomes. International Review of Administ
Sciences, 86(3), 479-495. https://doi.org/10.1177/0020852317704501

Mohamed, A. (2019). The effect of talent management processes on knowledge creation: A case of Australian higher education. An International business Journal, 17(4), 248-260.

MoH. (2018). Ministry of Health Draft Health Policy. Lilongwe: Government Press.

Mousa, M., \& Ayoubi, R.M. (2019). Talent management practices: Perceptions of academics in Egyptian public business schools. Journal of Management Development, 38(10), 833-846. https://doi.org/10.1108/jmd-01-2019-0030

Mukweyi. (2016). An investigation of the influence of talent management practices on healthcare professionals at Kijabe Mission Hospital in Kenya. Journal of Management Development, 24(9), 807-818.

Mwanzi, K., Wamitu, N., \& Kiama, B. (2017). Multiple commitments: A conceptual framework and empirical investigation in a community health service trust. British Journal of Management, 13(4), 337-357. https://doi.org/10.1111/1467-8551.00250

Nafei, W. (2015). The effects of talent management on service quality: A study on commercial banks in Egypt. International Business Research, 8(4), 41-58. https:// doi.org/10.5539/ibr.v8n4p41

Ngozwana, K., \& Rugimbana, R. (2011). Assessment of talent retention strategies: The case of a large South African company (CSA). African Journal of Business Management, 5(5), 1524-1527.

Obinna, B. (2015). The task of attraction and retention of academic staff in Nigeria universities. Journal of Management and Strategy, 7(2), 27-43. https://doi. universities. Journal of
org/10.5430/jms.v7n2p9

Othman, A.E., \& Khalil, M.H. (2018). Lean talent management: A novel approach for increasing creativity in architectural design firms. Journal of Engineering, Construction and Architectural Management, 25(10), 1355-1375. https://doi. org/10.1108/ECAM-07-2017-0139

Othman, A.E., \& Sumardi, W.A. (2014). Talent management at Steel Case Manufacturing, Malaysia: Managing high performance. Journal of Emerald Emerging Markets Case Studies, 4(6), 1-10.

Ozuem, W., Lancaster, G., \& Sharma, H. (2016). In search of the balance between talent management and employee engagement in human resource management Journal of Labour Relations Management, 6(2), 49-62.

Plessis, L.D., Barkhuizen, N., Stanz, K., \& Schutte, N. (2015). The management side of talent: Causal implications for the retention of generation $\mathrm{Y}$ employees. The talent: Causal implications for the retention of generation Y employees. The
Journal of Applied Business Research, 31(5), 1767-1780. https://doi.org/ Journal of Applied Busine
$10.19030 / j a b r . v 31 i 5.9390$

Perri, K.M. (2014). Principles of evaluation and research for health care programs. London: Jones \& Bartlett Publisher.

Phomnuisuk, S., \& Omar, S. (2016). Computational Intelligence in information system. Proceeding of the Computational intelligence in information systems Conference, $3(5), 58-63$.

Ramli, A.A., Isa, A., Baharin, N.L., \& Ibrahim, H.I. (2018). The role of talent management in the relationships between employee engagement: A study of GLCs. MATEC Web of Conferences, 150, 1-6. https://doi.org/10.1051/matecconf/201815005060

Salvador, C.A., Fernandez, F., \& Maria, G. (2017). Job satisfaction of nurses working in hospital units of northern Portugal. Revista de Enfermagem Referência, 4(15), hospital units of northern Portugal. Revista

Schreuder, R., \& Noorman, S. (2019). Strategic talent management: Creating strategic value by placing top talents in key positions. Development and Learning in Organizations: An International Journal, 33(1), 1-4. https://doi.org/10.1108/dlo09-2018-0120

Scott, F., \& Nahamin, B. (2017). Talentship, talent segmentation, and sustainability: A new HR decision science paradigm for a new strategy definition. Human Resource Management, 44(2), 129-136.

Shalonda, S. (2019). Factors influencing job satisfaction of registered nurses working in Public hospitals in Windhoek, Namibia. Academy of Management Journal, 54(4), 779-796.

Sinclair-Maragh, G., Jacobs-Gray, N., \& Brown-Roomes, N. (2018). A case of talent management practices in motivating fast food service employees. Journal of Emerald Emerging Marke
EEMCS-07-2016-0153

Skinner, V., Madison, J., \& Humphries, J. (2017). Job satisfaction of Australian nurses and midwives: A descriptive research study. Australian Journal of Advanced Nursing, 29(4), 19-27.

Stoffers, J., \& Van der Heijden, B. (2014). An innovative work behaviour enhancing employability model moderated by age. European Journal of Training and Development, 42(4), 43-163. https://doi.org/10.1108/EJTD-10-2016-0074

Tasha, S., Ali, M., \& Ahmadzadeh, M. (2016). The effects of talent management on employees performance in Oil Jam Petrochemical Complex (Oil JPC): The mediating role of job satisfaction. International Journal of Economics and Finance, 8(6), 226-238.

Thanh, T., \& Nguyeh, H. (2016). Factors related to job satisfaction of professional nurses, Hanoi, Vietnam. European Scientific Journal, 12(23), 401-411. https://doi. org/10.19044/esj.2016.v12n23p401 
Tyskbo, D. (2019). Talent management in a Swedish public hospital. Personnel Review, 48(6), 1611-1633. https://doi.org/10.1108/pr-05-2018-0158

Wahba, M. (2015). Talent management practices effect on employee engagement: Applied in logistics sector in Egypt. In Proceedings of annual Republique, Paris.
Whysall, Z., Owtram, M., \& Brittain, S. (2019). The new talent management challenges of Industry. Journal of Management Development, 38(2), 118-129. https://doi. org/10.1108/JMD-06-2018-0181

Yung, Z. (2010). Talent management of western MNCs in China: Balancing global integration and local responsiveness. Journal of World Business, 45(2), 160-178. https://doi.org/10.1016/j.jwb.2009.09.013 